\title{
The Protective Effects of Topical Cocoa Extract Lotio on Albino Mice to the Level of 8-OHdG After Ultraviolet B Exposure
}

\author{
Ramona Utami $^{1}$, Anis Irawan Anwar ${ }^{1}$, Khairuddin Djawad ${ }^{1}$, Anni Adriani ${ }^{1}$, Siswanto Wahab ${ }^{1}$, \\ Burhanuddin Bahar ${ }^{2}$
}

${ }^{1}$ Departement of Dermatology and Venereology, Medical Faculty, Hasanudin University, Makassar, Indonesia

${ }^{2}$ Departement of Biostatistic, Medical Faculty, Hasanuddin University, Makassar, Indonesia

Email address:

ramonautami@gmail.com (R. Utami)

\section{To cite this article:}

Ramona Utami, Anis Irawan Anwar, Khairuddin Djawad, Anni Adriani, Siswanto Wahab, Burhanuddin Bahar. The Protective Effects of Topical Cocoa Extract Lotio on Albino Mice to the Level of 8-OHdG After Ultraviolet B Exposure. American Journal of Clinical and Experimental Medicine. Vol. 5, No. 2, 2017, pp. 46-49. doi: 10.11648/j.ajcem.20170502.14

Received: January 25, 2017; Accepted: February 10, 2017; Published: March 2, 2017

\begin{abstract}
Ultraviolet B radiation (UVB) often cause oxidative stress, through the reactive oxygen species (ROS) formation and produce DNA damage. This study aims to assess the protective effects of topically cocoa extract lotio against DNA damage by measure of $8-\mathrm{OHdG}$ level in albino mice after UVB exposure. This study was conducted in Makassar, South Sulawesi, using 20 Swiss albino mice, aged 6-9 weeks, weight 20-30 grams. Mice were divided into 3 groups: The first group is a control group or negative control (without cocoa extract and without UVB exposure, consist 4 mice), the second is UVB control group exposure with UVB $450 \mathrm{~mJ} / \mathrm{cm}^{2}$ three times a week for 12 weeks without topical cocoa extract (4 mice) and the third group is mice with extract cocoa 200, 400 and 800 ppm every day, 20 minutes before exposure with UVB $450 \mathrm{~mJ} / \mathrm{cm}^{2}$ three times a week for 12 weeks (each concentration of cocoa extracts consist of 4 mice). At 24 hours after last exposure all mice were terminated and excisional biopsy on the dorsal skin of the size of $1 \times 1 \mathrm{~cm}$ and performed 8-OHdG ELISA. The results show there was significant difference $(\mathrm{p}<0.05)$ between the control group UVB with negative control and cocoa 800 $\mathrm{ppm}$. The $800 \mathrm{ppm}$ cocoa extract is the most effective to the reduction of 8-OhdG level.
\end{abstract}

Keywords: 8-OHdG, Cocoa Extract Lotio, UVB

\section{Introduction}

UVB radiation is sunlight highly genotoxic and 1000 times more capable of causing sunburn than UVA. UVB is almost completely absorbed by the epidermis and relatively few that reach the dermis, inducing DNA direct and indirect damage. UVB is absorbed directly by DNA which cause direct damage to the DNA through photochemical reactions that efficiency depends on the wavelength of UV energy absorption by DNA, which DNA base is directly absorb photons at a wavelength of UVB. [1, 2] Reaction with carbonyl groups and double carbon bond in areas adjacent pyrimidine, lead the specific photoproducts formation such as cyclobutane pyrimidine dimers (CPDS), 6-4 pyrimidinepyrimidone photoproducts ((6-4) $\mathrm{PP})$ is a product of mutations in epidermal cells followed cancer formation.
DNA damage indirect produced by ROS that facilitates oxidation DNA. [2-6] UVB is also known as the upregulation of gene expression through the pathway, signal transduction which plays a role in the formation of skin cancer at a promotional rate tumor. [2]

Reactive oxygen species is a term used to oxidant group consisting of free radicals, such as superoxide radical anion $\left(\mathrm{O}_{2}-\right)$, carbon dioxide free-radical $\left(\mathrm{CO}_{2^{-}}\right)$and hydroxyl freeradical ( $\mathrm{OH}-)$ or molecular species capable of generating free radicals, such as hydrogen peroxide $\left(\mathrm{H}_{2} \mathrm{O}_{2}\right)$. [7, 8] free radicals are chemical component reactive that has a single unpaired electron in its outer orbit. Electron pairs usually produce highly free radicals reactive by reaction with adjacent molecules, such as proteins, fats, carbohydrates and nucleic acid. [9] ROS percentage will increase during infection, exercise, exposure to pollutants, sunlight and 
radiation ionisasi. [7] At the high concentrations, ROS can act as a mediator basis of structural cells damage, proteins and nucleic acid known as "oxidative stress". ROS-mediated oxidative stress which resulted in damage to the DNA with the formation of 8-hydroxy-2'-deoxyguanosine (8-OHdG), which is one of the major products of oxidative damage and mutagenic lot to detection. [10]

8-hydroxy-2' deoxyguanosine is one of the major oxidative modified DNA base product, which was first reported by Kasai et al to be formed on interaction hydroxyl radical $\left(\mathrm{OH}^{-}\right)$ and singlet oxygen photodynamic action with DNA. 8-OHdG is a result of lesions oxidative damage to DNA are mutagenic in mamalian cells. Several studies reported the higher content of $8-\mathrm{OHdG}$ in human cancer tissue and animal tumor tissue comparison to normal tissue. $[11,12] 8-\mathrm{OHdG}$ is a biomarker of oxidative DNA damage and measured levels of $8-\mathrm{OHdG}$ is used as an evaluation of oxidative stress. [12] Chemopreventive strategy the new and promising for prevention, inhibit and suppress carcinogenesis through the use of natural plant products. The content suggested innatural product theis to have a function as antimutagenic, anticarsinogenesis, inhibit the effects of cell proliferation and function as antioxidants are associated with good chemopreventive agent. epidemiological studies show that consumption of fruit or vegetable associated with the prevention of carsinogenesis. [13, 14] Process Polyphenols have antioxidants capacity and beneficial to human health. Cocoa is reported to have higher antioxidants capacity than tea and red wine and a rich source of polyphenols. In recent years, several studies have focused on the cocoa polyphenols, especially flavonoids that function as potent antioxidants for human health. [15] cocoa flavonoids are known to have the antioxidants effect by scavenging ROS, inhibit key enzymes and promote the defense antioksidan. [16] Flavonoids can prevent DNA damage caused by free radicals or carcinogens agents through different pathways, radical scavenging directly, modulating enzymes associated with oxidative stress and alter metabolism procarsinogenic. [17]

\section{Materials and Methods}

\subsection{Study Design}

This study was a true experimental research design. This study was conducted in Animal Laboratory of Hasanuddin University, ELISA examination were conducted at the Biomolecular Laboratory, Makassar.

\subsection{Samples and UVB Radiation}

Female swiss albino mice species aged 6-9 weeks, weight 20-30 grams. Mice were maintained for at least 1 week in standard conditions. The room temperature $\left(28 \pm 2{ }^{\circ} \mathrm{C}\right), 50$ humidity $\pm 10 \%$ and light cycle room with 12 hours light and 12 hours dark cycle. Sample Research: Twenty mice were divided into 3 treatment groups: group I without treatment or a negative control (4 mice), group II mice by exposure to UVB $450 \mathrm{~mJ} / \mathrm{cm}^{2}$ three times a week for 12 weeks (2 minutes/session) without topical extracts of cocoa (4 mice) and group III mice with cocoa extract 200, 400 and 800 ppm every day, 20 minutes before exposure with UVB $450 \mathrm{~mJ} / \mathrm{cm}^{2}$ three times a week for 12 weeks (each concentration of cocoa extracts consist of 4 mice). At 24 hours after last exposure all mice were terminated and excisional biopsy on the dorsal skin of the size of $1 \times 1 \mathrm{~cm}$ and performed $8-\mathrm{OHdG}$ ELISA.

\subsection{Cocoa Extract Lotio}

Cocoa extract lotio with a concentration of 200, 400 and $800 \mathrm{ppm}$ were made in the form of lotion preparations obtained from laboratory Phytochemicals Pharmacognosy Faculty of Pharmacy, Hasanuddin University.

\subsection{8-OHdG ELISA}

After animals were sacrificed, the dorsal skin was collected, fixed in $0,9 \% \mathrm{NaCl}$, then processed to ELISA measure. For ELISA measure, the first is a $50 \mu \mathrm{L}$ of each standard or sample was added and then immediately added $50 \mu \mathrm{L}$ Biotinylated detection antibody. Incubation for $45 \mathrm{~min}$ at $37^{\circ} \mathrm{C}$, then aspirated and washed 3 times. After $100 \mu \mathrm{L}$ HRP conjugate was added and incubated for $30 \mathrm{~min}$ at $37^{\circ} \mathrm{C}$, then aspirated and wash five times. Add $90 \mu \mathrm{L}$ substrate reagents, incubation 15 minutes at a temperature of $37^{\circ} \mathrm{C}$. Add $50 \mu \mathrm{L}$ Stop abruption and immediately read at $450 \mathrm{~nm}$, then the calculation results.

\subsection{Statistical Analysis}

The data were statistically analyzed using SPSS version 22.0. Data is displayed using ANOVA test, followed by Post Hoc test.

\section{Results}

This study used 20 mice albino selected randomly and were divided into 3 treatment groups consisting of 3 group: control without any treatment (negative control), UVB alone and UVB with cocoa extract lotio content of the natural materials used in extracts of cocoa is a flavonoid with concentrations of 200 , 400 and $800 \mathrm{ppm}$ containing $14.48 \mathrm{mg}, 29.68 \mathrm{mg}$ and 59.36 $\mathrm{mg}$ of total content of flavonoid each. From the results of the ELISA levels of 8-OHdG was found that there are significant differences as between the various treatment groups ( $p>0.05)$ as evidenced by ANOVA. However, the increasing concentration of cocoa extract showed decreased levels of 8OHdG. The level of 8-OHdG highest in UVB control group and lowest in cocoa 800 ppm group (Table 1).

Table 1. Comparison of 8-OHdG levels according to the analysis of all variants (ANOVA).

\begin{tabular}{llll}
\hline Groups & N & Mean \pm SD & p \\
\hline Negative Control & 4 & $1,4425 \pm 1,3446$ & 0,109 \\
UVB Control & 4 & $3,4950 \pm 0,8134$ & \\
Cocoa 200 ppm & 4 & $2,8750 \pm 0,8083$ & \\
Cocoa 400 ppm & 4 & $2,0975 \pm 1,0545$ & \\
Cocoa 800 ppm Total & 4 & $1,3860 \pm 1,7638$ & \\
& 20 & $2,2176 \pm 1,4022$ & \\
\hline
\end{tabular}


Comparative test the levels of $8-\mathrm{OHdG}$ between each group with Post Hoc test and found that are differences significant as between the control group UVB with a negative control $(\mathrm{p}<0.034)$ and between the control group with cocoa UVB 800 ppm ( $<<0.023)$. Whereas among UVB control group with other cocoa extract not differences significantly (Table 2).

Table 2. Comparison of the levels of 8-OHdG among the treatment groups.

\begin{tabular}{llll}
\hline (I) Group & (J) Group & Mean Diferrent (I-J) & p \\
\hline Negative Control & UVB Control & $-2,05$ & 0,034 \\
& Cocoa 200 & $-1,43$ & 0,126 \\
& Cocoa 400 & 0,65 & 0,471 \\
& Cocoa 800 & 0,05 & 0,947 \\
Cocoa UVB & Cocoa 200 & 0,62 & 0,494 \\
& Cocoa 400 & 1,39 & 0,135 \\
& Cocoa 800 & 2,10 & 0,023 \\
Cocoa 200 & Cocoa 400 & 0,77 & 0,393 \\
& Cocoa 800 & 1,48 & 0,096 \\
Cocoa 400 & Cocoa 800 & 0,71 & 0,410 \\
\hline
\end{tabular}

*Post Hoc Test

\section{Discussion}

The formation of $8-\mathrm{OHdG}$ were triggered by UV on the skin indicates high levels in the epidermis 7 days after exposure. Nishigori and Hattori (2004) reported that 8-OHdG induced by UV in skin mouse removal obtained slowly and remained at high levels in the epidermis 7 days after exposure. [18] 8-OhdG is the best biomarker to determine DNA damage and measuring the levels of $8-\mathrm{OHdG}$ is used as an evaluation of the oxidative stress. $[12,19]$ Several studies have reported that the obtained 8-levels OHdG were higher in cancer tissue compared to normal tissue. Decrease in 8OHdG level indicate a decrease in the oxidative damage at DNA. Kumar et al (2012) showed that the levels of 8-OHdG higher in was squamous cell carcinomas compared to a healthy control group. [11]

In this study, no significant difference to the levels of 8OHdG among the treatment groups $(\mathrm{p}=0.109)$. Then do the test Post Hoc and found significant differences as between the control group and the negative control UVB with cocoa $800 \mathrm{ppm}$. 8-OHdG levels highest was in the control group UVB and the lowest found was in the group given protective cocoa extract concentration of $800 \mathrm{ppm}$ (table 1). Chemopreventive a promising new strategy for prevention, inhibit and suppress carcinogenesis through natural products. [13] Cocoa plant is a higher antioxidants substances that have potent antioxidants capacity compared to other natural resources and is associated with the flavonoid. Flavonoids cocoa may prevent DNA damage caused by free radicals or carsinogenesis agents. [20] Martin et al (2008) reported cocoa polyphenols have a protective effect against oxidative stress in human hepatocellular carcinoma. [21] Cocoa therapy prior to induction of oxidative stress preventing DNA damage and increase the activity of antioxidant enzymes gluthatione reductase and gluthatione peroxidase on induced cell prooxidant tert-buthylhydroperoxide. [17] In this study also showed an increase in protective effect on levels of 8$\mathrm{OHdG}$ in line with increasing concentrations of the cocoa extract.

The study by Wahab et al (2014) showed that application the topical of cocoa extract concentrations of 400 and 800 ppm have protective effect against skin cancer formation in albino mice by exposure to DMBA and TPA with the best protective effects on cocoa concentration of $800 \mathrm{ppm}$. [22] Adriani et al (2014) also reported a protective effect of cocoa extract on the expression of $8-\mathrm{OHdG}$ and PCNA in albino mice by exposure to UVB. [18]

\section{Conclusion}

From this study, application of cocoa extract lotio is effective in protective to reduce of $8-\mathrm{OhdG}$ level and the 800 ppm cocoa extract is the most effective.

\section{References}

[1] Ichihashi $M$, Ando $H$, Yoshida $M$, Niki $Y$, Matsui $M$. Photoaging of the skin. JAAM. 2009; 6 (6): 46-59.

[2] Ichihashi M, et al. UV-induced skin damage. J Toxicol. 2003: 21-39.

[3] Gozaga ER. Role of UV light in photodamage, skin aging and skin cancer. Am J Clin Dermatol. 2009; (10): 9-24.

[4] Kryston TB, Georgiev AB, Pissis P. Role of oxidative stress and DNA damage in human carcinogenesis. Elsevier. 2011: 193-201.

[5] D'Orazio J, Jarret S, Ortiz AA, Scott T. UV radiation and the skin. Int. J. Mol. Sci. 2013; 14: 12222-48.

[6] Svobodova A, Walterova D, Vostalova J. Ultraviolet light induced alteration to the skin. Biomed Pap Med Fac. 2006; 150 (1): 25-38.

[7] Kunwar A, Priyadarsini KL. Free radicals, oxidative stress and oxidative damage in carcinogenesis. $J$ Med Allied Sci. 2011; 1: 53-60.

[8] Costa A, Dahirel AS, Grigoriou FM. The role of reactive oxygen species and metabolism on cancer cells and their microenvironment. Sem. Canc Biol. 2014; 25: 23-32.

[9] Grigorov B. Reactive oxygen species and their relation to carcinogenesis. Trak J Sci. 2012; 10: 83-92.

[10] Tandon R, Bhakar M, Pande D, Karki K, Negi R, Khana HD. Oxidative stress induced lipid peroxidation and DNA adduct formation in the pathogenesis of multiple myeloma and lymphoma. J Psy and Bio. 2013: 1-9.

[11] Kumar A, Paint MC, Singh HS, Sashi, Khandelwal. Assessment of the redox profile and oxidative DNA damage (8-OHdG) in squamous cell carcinoma of head and neck. $J$ Canc Res Ther. 2012; 8: 254-61.

[12] Klaunig JE, Kamendulis LM, Hocevar BA. Oxidative stress and oxidative damage in carcinogenesis. Tox Pathol. 2010; 38: 96-109. 
[13] Manoharan S, Selvan MV. Chemopreventive potential of geraniol in 7, 12-dimethylbenz (a) anthracene (DMBA) induced skin carcinogenesis in Swiss albino mice. J Environ Biol. 2012; 33: 255-60.

[14] Jain T, Tater A, Vijayvargiya I, Goyal PK. Prophylactic Role of Carissa Carandas Against DMBA Induced Skin Carcinogenesis in Swiss Albino Mice. IJIRR. 2015; 2: 426-32.

[15] Hii CL, Law CL, Suzannah S, Misnawi, Cloke M. Polyphenols in cocoa (Theobroma cacao L). As J Food Ag-Ind. 2009; 2: 702-22.

[16] Martorrel P, et al. A Cocoa Peptide Protects Caenorhabditis elegans from Oxidative Stress and $\beta$-Amyloid Peptide Toxicity. Biopolis.es. 2013; 8: 1-11.

[17] Martin MA, Goya L, Ramos S. Potential for preventive effects of cocoa and cocoa polyphenols in cancer. Depart Met Nutr. 2012: 1-66.

[18] Adriani A, Armin SA, Massi MN, Djawad K. Protective effects of daily topical cocoa extract to the expression of 8 OhdG and PCNA on UVB-exposed albino mice. Int $J$ Biol Med Res. 2014; 5 (4): 4607-11.

[19] Can EC, et al. DNA damage and lipid peroxidation in several types of cancer. J Pharm Sci. 2012; 35: 125-32.

[20] Martin MA, Goya L, Ramos S. Preventive Effects of Cocoa and Cocoa Antioxidants in Colon Cancer. Depart Met Nutr. 2016: 2-14.

[21] Andujar, Recio MC, Giner RM, Rios JL. Cocoa Polyphenols and Their Potential Benefits for Human Health. Oxidative medicine and cellular longevity. 2012: 1-24.

[22] Wahab S, Massi MN, Gemini A, Djawad K. Protective effect of cocoa extract on albino mice skin tumor after exposure to 7,12-dimethylbenz (a) anthracene (DMBA) and 12-OTetradecanoylphorbol-13-Acetate (TPA) Malondyaldehyde (MDA) analysis and histopathology. Int J Biol Med Res. 2014; 5 (4): 4648-53. 